\title{
Consumption of superplasticizer admixture for different cements and their binder efficiency
}

\section{Consumo de aditivo superplastificante em diferentes cimentos e a eficiência dos ligantes}

R. T. CECEL a

rafael.cecel@Ime.pcc.usp.br https://orcid.org/0000-0003-1681-5071

P. C. R. A. ABRÃO

pedro.abrao@lme.pcc.usp.br https://orcid.org/0000-0002-3416-3196

F. A. CARDOSO

fabio.cardoso@lme.pcc.usp.br https://orcid.org/0000-0003-2642-0428

V. M. JOHN a
vanderley.john@Ime pcc.usp.br https://orcid.org/0000-0002-0588-8382

\begin{abstract}
The optimum content of ether polycarboxylate-based superplasticizer, determined by rotational rheometry, and its effects on the environmental impacts of concretes were studied for cement and limestone filler. To assess the consistency and water reduction, flow-table tests were performed. Then, cement content reduction and binder and carbon intensity indexes were determined through estimation based on theoretical concretes. The evaluated pure and blended cements present significant variability of the optimum consumption of the admixture. The fillers consumed less superplasticizer per area than the other materials and compositions with fillers allowed for greater reduction of water content. The mixtures with superplasticizer presented lower cement rate and binder and carbon intensity indexes. The usage of this type of admixture in optimal content can reduce environment impacts, according to the parameters analyzed.
\end{abstract}

Keywords: superplasticizer, ether polycarboxylate, cement, binder efficiency, environment impacts.

\section{Resumo}

Foram estudados, em cimentos e fillers calcários, os teores ótimos de superplastificante (base policarboxilato éter), determinados através de reometria rotacional, e estimados seus efeitos nos impactos ambientais de concretos. Ensaios de espalhamento de argamassas em mesa de consistência foram feitos para determinação da redução de água e estimação de redução do cimento e intensidades de ligantes (IL) e $\mathrm{CO}_{2}$ (IC) em concretos teóricos. Os cimentos estudados apresentaram significante variação de consumo de superplastificante. Os fillers consumiram menos aditivo por unidade de área do que os demais materiais e suas composições apresentaram maior redução de água. O uso de superplastificantes levou à redução do consumo de cimento e das intensidades de ligante e carbono. A otimização do teor de superplastificante se mostrou eficiente para a redução de impactos ambientais.

Palavras-chave: superplastificante, policarboxilato éter, cimento, eficiência, impacto ambiental.

Universidade de São Paulo, Escola Politécnica, Departamento de Engenharia Civil, São Paulo, SP, Brasil. 


\section{Introduction}

Reducing greenhouse gas emissions is one of the greatest concerns and challenges today. Among them, the carbon dioxide $\left(\mathrm{CO}_{2}\right)$ is the anthropogenic gas that presents the greater responsibility in the phenomenon [1]. The cement industry is the second largest responsible for the emission of this gas [2] and the production of clinker corresponds to up to $7 \%$ of the emissions [3,4]. For this reason, it requires alternatives for increasing energy efficiency, partial substitution of clinker for additional cementitious materials, use of coprocessing for energy generation and optimization of binder application [5]. Another means of reducing emissions occurs through the minimization of the volume of cement in the composite mixtures, possibly even by using plasticizers and superplasticizers that allow the reduction of water content and the improvement of rheological behavior. Corrêa [6], has shown that the performance of plasticizers and polyfunctional admixtures in concretes, can reduce cement consumption in concretes by up to $10 \%$, maintaining or improving their fluidity.

Admixtures are products added in the cementitious composite mixtures in order to modify their properties in the fresh and/or hardened state. They are generically categorized as: (i) plasticizers and superplasticizers, or water reducers; (ii) air-entraining; (iii) accelerators and (iv) retarders;(v) strength accelerators [7]; and (vi) viscosity enhancing admixtures [8]. Admixtures that present two or more combined functions are called polyfunctional.

Plasticizers and superplasticizers are polymers, commonly naphthalene, melanin, lignosulfonate, polycarboxylate, acids or esters-based [9]. They are adsorbed on the surface of the particles, exerting the dispersion function by electrostatic, steric or electrosteric stabilization [10], making it possible to reduce water. They can present compatibility variation in the cements as a function of the characteristics of the binder and the additions $[11,12]$ and their efficiency varies according to the molecular weight and length of the main and lateral chains of which they are composed, and the larger these are, the greater their efficiency [13]. These admixtures are expensive products in mortars and concretes. The lower the consumption, the lower the cost of the composite. However, due to the variations mentioned above, the dosage suggested by the manufacturers may be imprecise [14], causing loss of workability, due to insufficiency or excess on dosage [15], or an increase in cost by excessive content. Thus, studies to determine the demand of admixtures for each material are useful for composition optimization.

The objective of this study is to evaluate the admixture demand and its variation for different types of commercial cements and cements blended in the laboratory with different contents of limestone and to estimate the potential to reduce cement consumption and environmental impacts on concretes.

\section{Methodology}

This study was composed of three steps: (i) determination of the optimal consumption of superplasticizer admixture; (ii) assessment of water reduction potential; and (iii) estimation of cement content reduction capacity and environmental impacts. The study of admixture consumption was performed by rotational rheometry of pastes and evaluation of their deflocculation curves. Different types of commercial cements obtained from different regions of Brazil and two limestone fillers were studied. The potential of water reduction was analyzed by the consistency data (flow table values) of the mortars and, in order to estimate the cement reduction capacity and the efficiency of the binder and $\mathrm{CO}_{2}$ emission factor, the inference was made for concrete using theoretical Abrams curves. In this last step, the cements blended in laboratory were not used.

\subsection{Materials}

Cements from different manufacturers were used in the study, including: CPII-E (blended with slag), CPII-F (blended with filler); three

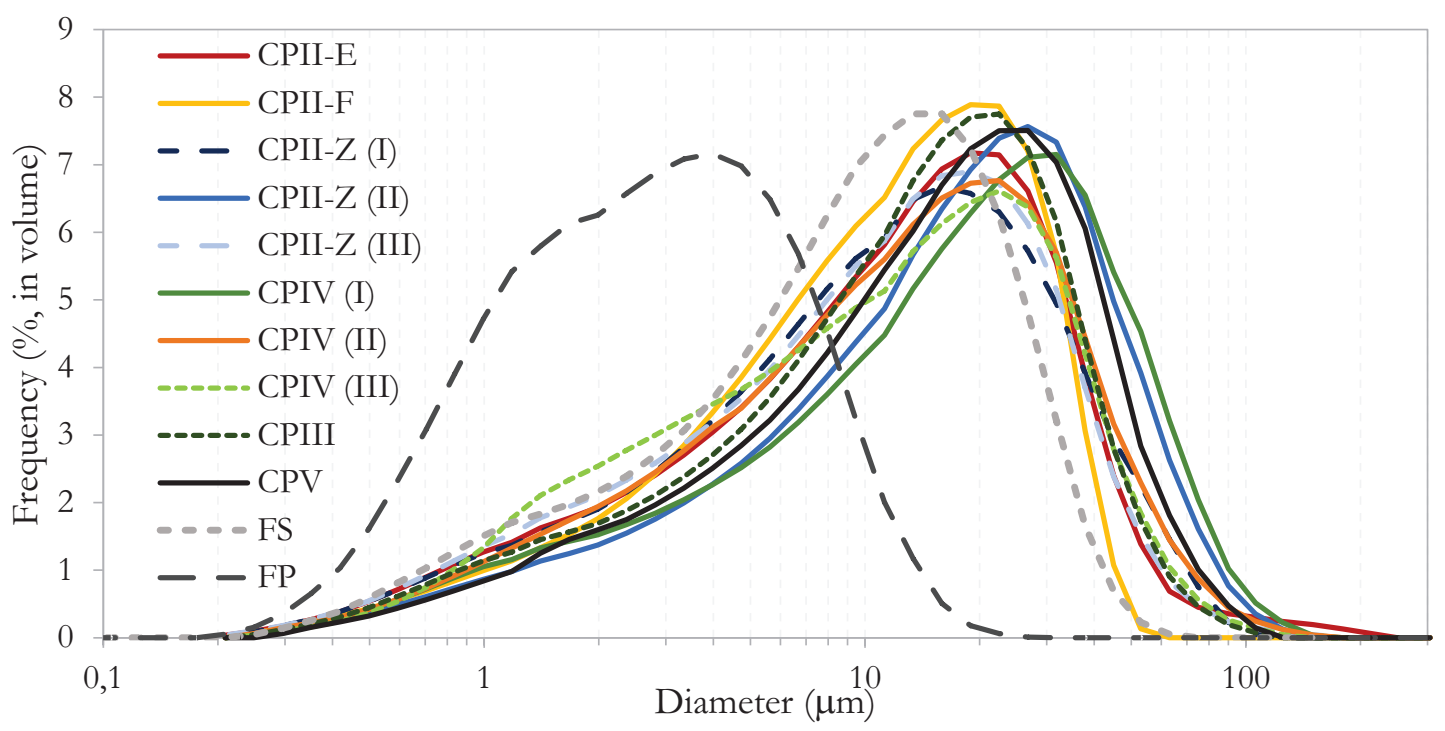

Figure 1

Granulometric curves of cements and fillers used 
CPII-Z (blended with pozzolan) and CPIV with high pozzolan content of different natures; CPIII (blended with high content of slag) and CPV (high-early strength, high clinker content). The substitution limestone filler (FS) and the performance filler (FP) had a purity of 94.0 and $98.7 \%$, respectively. For the consistency analysis, made with mortars, Brazilian normal standard sand was used, as indicated in NBR 7214 [16]. The mixing water was previously deionized.

The superplasticizer used was a commercial admixture ADVA CAST 527 (Grace Construction Products), described by the manufacturer as "alkaline aqueous polymer solution used as a highly efficient water reducer". Its base is polycarboxylate ether, which acts by electrosteric stabilization and presents solids content of $40 \%$ and specific mass of $1.075 \mathrm{~g} \cdot \mathrm{cm}^{-3}$ [17].

The granulometry of the cements and fillers used was obtained by laser diffraction (Helos - Sympatec). In each sample, $0.20 \mathrm{~g}$ of each material was mixed with $50 \mathrm{~mL}$ deionized water in 1000RPM (IKA RW 20) for 1 minute. The suspension was then added to the apparatus, subjected to ultrasonic dispersion for 1 minute and analyzed in deionized water. The curves are shown in Figure 1. It can be observed that all cements present similar particle size profiles, with CPII-F the finest fineness. The FS filler has slightly finer particle size than the CPV, while FP is the minor size material analyzed, presenting a potential filling function in common cements.

The specific gravity (SG) and specific surface area $\left(\mathrm{SSA}_{\mathrm{BET}}\right)$ of the materials were obtained by Helium gas pycnometry (Multipycnometer, Quantachrome MVP 5DC) and by adsorption of Nitrogen (BET method, Belsorpmax - Bel Japan), respectively. The volumetric surface area (VSA) corresponds to the product of ASS $_{B E T}$ and SG. The shape factor (SF) was obtained by the relation between the $S S A_{B E T}$ results and the specific surface area obtained by laser diffraction $\left(\mathrm{SSA}_{\mathrm{LD}}\right)$, which considers the particles as perfectly smooth spheres [18]. Thus, the further away from 1 is this factor, the more irregular and/or rougher is the particle. The data are presented in Table 1.

Although the granulometric curves of the cements are similar, there are significant variations in the specific surface area, especially in CPII-Z cements, except for CPII-Z (I) and CPIV. The variation becomes clearer when we analyze the shape factor, indicating that the particles of these materials are more irregular and/or rougher than the others.

\subsection{Compositions}

The compositions made include two types of materials: cement pastes and mortars. The first were produced for the study of superplasticizers consumption. The mortars were produced to assess flow-table spread and water reduction capacity.

\subsubsection{Pastes}

To estimate the optimal superplasticizer consumption, pastes of $100 \mathrm{~g}$ of powder were prepared. The water/fines ratio (w/f) was 0.35 . The superplasticizer admixture content was adjusted for each sample. The water added in the mixture was corrected to consider the water present in the admixture and kept $w / f$ ratio constant.

\subsubsection{Mortars}

In the consistency study, mortars composed of 1: 3 (fines: sand) per mass, were prepared according to the dosage indicated in the Brazilian standard NBR 7215 [19] and Table 2, with w/f adjusted for each sample according to the desired spread for the consistency study, as discussed in 2.4.2. All mortars had between 76.3 and $78.1 \%$ of sand in dry volume of solids, due to differences of specific gravity of the fines.

In the case of mortars with filler, the fines used are a combination of CPV, FS and FP, covering a composition with medium content (CP MF) and a high content (CP HF) of the mineral addition, as indicated in the proportions of Table 3 . The superplasticizer admixture contents used were the optimum contents obtained in the study of admixture consumption as a function of the mass of the cement and filler. In compositions containing filler, the admixture was adjusted proportionally to the content of each type of fine material.

\subsection{Mix procedures}

\subsubsection{Pastes}

Mixing of the pastes occurred in three steps: (i) adding the water in the fines in five seconds; (ii) manual mixing with spoon for

\section{Table 1}

Physical properties of the cements used

\begin{tabular}{|c|c|c|c|c|c|c|c|c|c|}
\hline Material & $\begin{array}{l}\text { Strength } \\
\text { class } \\
\text { (MPa) }\end{array}$ & $\begin{array}{c}\text { SG } \\
\left(\mathrm{g} / \mathrm{cm}^{3}\right)\end{array}$ & $\begin{array}{l}\text { D10 } \\
(\mu \mathrm{m})\end{array}$ & $\begin{array}{l}\text { D50 } \\
(\mu \mathrm{m})\end{array}$ & $\begin{array}{c}\text { D90 } \\
(\mu \mathrm{m})\end{array}$ & $\begin{array}{l}\mathrm{SSA}_{\mathrm{BET}} \\
\left(\mathrm{m}^{2} / \mathrm{g}\right)\end{array}$ & $\begin{array}{c}\mathrm{SSA}_{\mathrm{DL}} \\
\left(\mathrm{m}^{2} / \mathrm{g}\right)\end{array}$ & $\begin{array}{c}\text { VSA } \\
\left(\mathrm{m}^{2} / \mathrm{cm}^{3}\right)\end{array}$ & SF \\
\hline CPII E & 40 & 3.04 & 1.94 & 13.38 & 38.05 & 1.13 & 0.41 & 3.43 & 2.76 \\
\hline CPII F & 40 & 3.01 & 2.35 & 12.66 & 31.78 & 1.18 & 0.38 & 3.56 & 3.12 \\
\hline CPII Z (I) & 32 & 3.10 & 1.98 & 12.76 & 40.72 & 1.3 & 0.41 & 4.03 & 3.17 \\
\hline CPII Z (II) & 32 & 2.96 & 2.83 & 18.91 & 52.06 & 1.19 & 0.31 & 3.52 & 3.84 \\
\hline CPII Z (III) & 32 & 2.98 & 1.84 & 12.52 & 37.15 & 2.41 & 0.44 & 7.18 & 5.48 \\
\hline CPIII & 40 & 2.97 & 2.23 & 14.71 & 38.76 & 0.99 & 0.37 & 2.94 & 2.67 \\
\hline CPIV (I) & 32 & 3.03 & 2.44 & 19.41 & 56.49 & 1.26 & 0.33 & 3.82 & 3.82 \\
\hline CPIV (II) & 32 & 3.15 & 2.16 & 13.92 & 42.79 & 1.45 & 0.36 & 4.57 & 4.03 \\
\hline CPIV (III) & 32 & 3.11 & 1.89 & 12.46 & 39.35 & 4.3 & 0.39 & 13.37 & 11.03 \\
\hline CPV & 40 & 3.08 & 2.72 & 17.14 & 46.26 & 1.64 & 0.30 & 5.05 & 5.45 \\
\hline FS & - & 2.74 & 1.46 & 8.83 & 23.09 & 1.16 & 0.50 & 3.18 & 2.32 \\
\hline FP & - & 2.76 & 0.73 & 2.49 & 7.17 & 3.73 & 1.13 & 10.29 & 3.30 \\
\hline
\end{tabular}


Table 2

Composition of mortars used in the study of consistency and reduction of water, in mass and volume

\begin{tabular}{|c|c|c|c|c|c|}
\hline \multirow{2}{*}{ Identification } & \multicolumn{2}{|c|}{ Parts (in mass) } & \multicolumn{3}{|c|}{ Composition (in volume) } \\
\hline & Fines & Sand & Fine (\%) & Sand $(\%)$ & Fine/Sand \\
\hline CPII E & \multirow{12}{*}{1} & \multirow{12}{*}{3} & 22.6 & 77.4 & 0.29 \\
\hline CPII F & & & 22.7 & 77.3 & 0.29 \\
\hline CPII Z (I) & & & 22.2 & 77.8 & 0.29 \\
\hline CPII Z (II) & & & 23.0 & 77.0 & 0.30 \\
\hline CPII Z (III) & & & 22.9 & 77.1 & 0.30 \\
\hline CPIII & & & 23.0 & 77.0 & 0.30 \\
\hline CPIV (I) & & & 22.6 & 77.4 & 0.29 \\
\hline CPIV (II) & & & 21.9 & 78.1 & 0.28 \\
\hline CPIV (III) & & & 22.2 & 77.8 & 0.28 \\
\hline CPV & & & 22.3 & 77.7 & 0.29 \\
\hline $\mathrm{CP} M F$ & & & 23.1 & 76.9 & 0.30 \\
\hline $\mathrm{CPHF}$ & & & 23.7 & 76.3 & 0.31 \\
\hline
\end{tabular}

\section{Table 3}

Proportions of the fines composed by CPV and limestone filler and used in the mortars CP MF and CP HF

\begin{tabular}{|c|c|c|c|c|c|c|}
\hline \multirow{2}{*}{$\begin{array}{c}\text { Fine } \\
\text { compositions }\end{array}$} & \multicolumn{3}{|c|}{ Composition (in mass) } & \multicolumn{3}{|c|}{ Composition (in volume) } \\
\hline & CPV & FS & FP & CPV & FS & FP \\
\hline CP MF & 0.61 & 0.11 & 0.28 & 0.58 & 0.12 & 0.30 \\
\hline $\mathrm{CP} \mathrm{HF}$ & 0.32 & 0.39 & 0.29 & 0.29 & 0.41 & 0.30 \\
\hline
\end{tabular}

50 seconds; and (iii) dispersion in a high energy rotating mixer of 10000rpm (Makita adapted) for 1.5 minutes. When superplasticizer was used, it was added together with water.

\subsubsection{Mortars}

The mortars were mixed according to the procedures indicated in NBR 7215 [19] and the model of Figure 2. Water is added to the bowl prior to mixing. The first step corresponds to the addition period of the cement and the homogenized sand, respectively. The second and fourth levels correspond to mixing at high speed, while the third step refers to the resting of the mortar, covered with wet tissue. The admixture, when used, was added to the water and homogenized prior to the mortar mixing.

\section{$2.4 \quad$ Methods}

The study was carried out in three different steps to determine: (i) optimum admixture consumption for each raw material; (ii) consistency profile as a function of water/fines ratio and evaluation of water reduction potential; and (iii) estimation of cement reduction capacity and assessment of binder efficiency and $\mathrm{CO}_{2}$ impact.

\subsubsection{Admixture consumption}

Some studies use standard tests to determine the consumption of dispersant admixtures, such as Slump and Marsh cone [20-23]. However, these types of tests evaluate the behavior only for a shear condition, keeping the behavior of the mixture under different stresses unknown [24]. Thus, for determination of the optimum admixture content, it is necessary to evaluate different shear rates. To analyze the superplasticizer admixture consumption, the pastes were submitted to the rotational rheometer test (MARS 60, Haake rheometer) immediately after the paste was mixed. The method used the stepped flow test, in two acceleration and deceleration

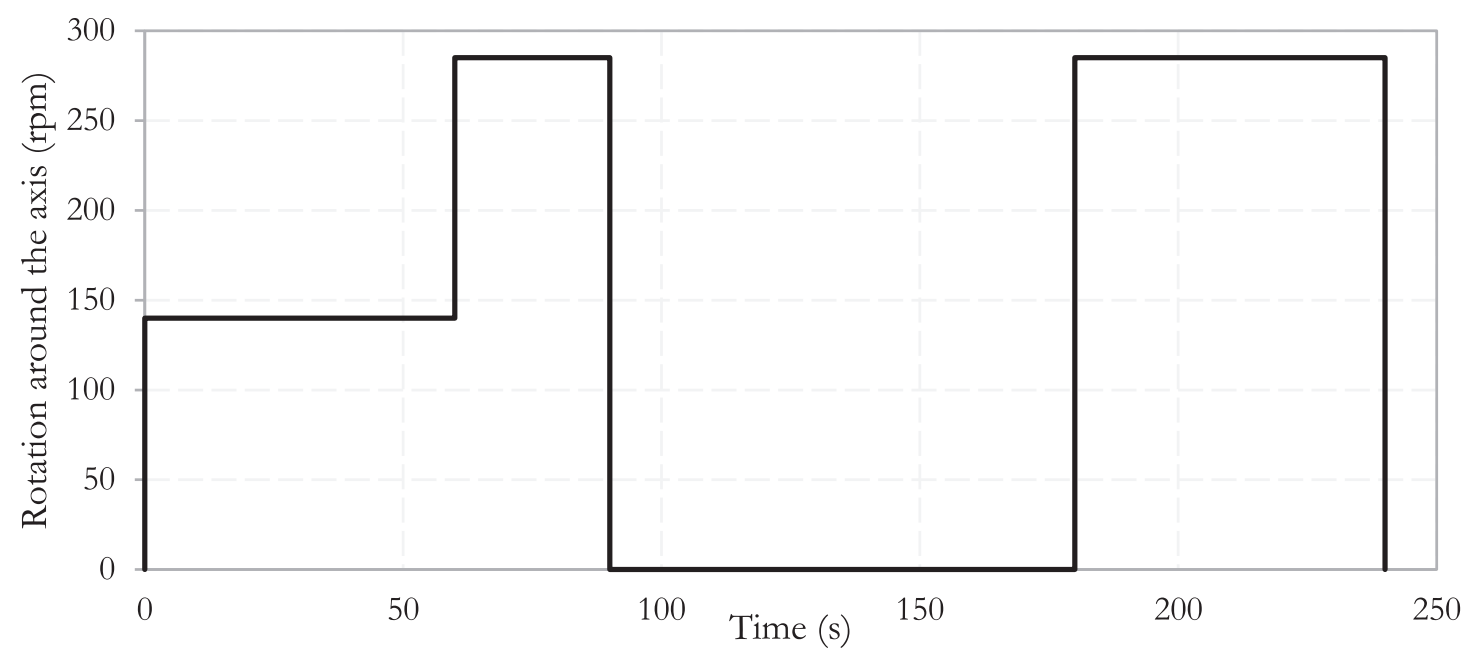

Figure 2

Mixing procedure of mortars according to NBR 7215, for study of consistency and water reduction 


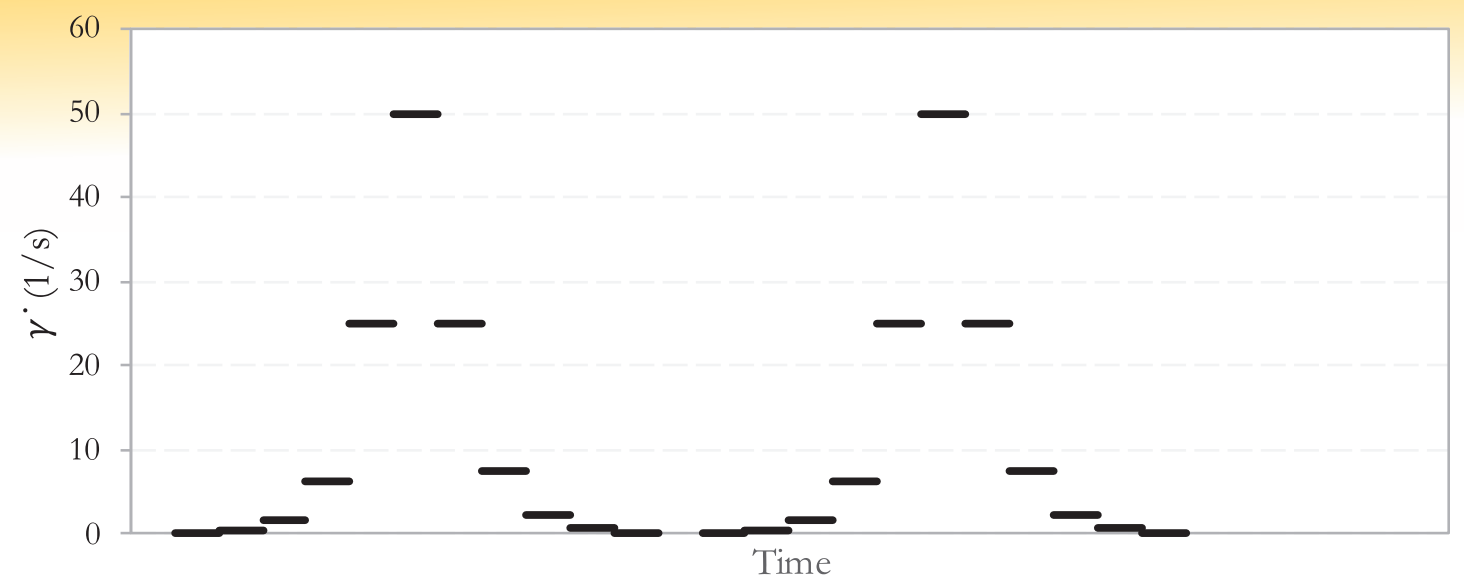

\section{Figure 3}

Stepped flow test step model to determine the rheological behavior of each paste composition. The duration at each level was 10 seconds

cycles, varying the shear rate $(\dot{\gamma})$ from 0 to $50 \mathrm{~s}^{-1}$, remaining for 10 seconds in each step, according to the model presented in Figure 3. The first cycle was performed only for standard conditioning (preshearing) of the paste mixture, while the second cycle was used for data collection. In this step, for each admixture content, it was analyzed: (i) shear yield stress $\left(\tau_{0}\right)$, where $\tau$ correspond to the shear stress in a fixed shear rate that tends to zero in the deceleration profile; and (ii) apparent viscosity $(\eta)$, obtained in shear rate equal to $50 \mathrm{~s}^{-1}[10]$. The admixture adjustments occurred arbitrarily after each test in a new sample until the saturation point was found in the deflocculation curve, where the two parameters mentioned above did not vary very much with the admixture addition, characterized in this study as the stabilization in three consecutive points in the curve. The optimal content was defined as the point immediately after the stabilization of the shear yield stress and apparent viscosity at $50 \mathrm{~s}^{-1}[25]$.

By the saturation point analysis, the specific consumption of superplasticizer, corresponding to the relationship between admixture consumption and specific surface area (BET), was evaluated. This parameter allows to analyze the specific consumption for the material already considering surface parameters.

\subsubsection{Consistency of mortar and water reduction to maintain same rheological behavior}

The study of the consistency of mortars occurred using commercial cements and compositions with filler, with and without admixture. Immediately after mixing, the mortars were tested in a flow-table, according to NBR 13276 [26], recording the respective spreads after thirty table falls in 30 seconds. One mortar was produced for each $w / f$ ratio. The results were recorded in three spread diameters, which comprised an average. For the cases where there was segregation, the record was made despising the water exuded in the peripheries.

The tests for each composition started from the w/f ratio of 0.48 , a value used by the Brazilian standard of strength classification of cements [19]. For each mortar produced afterwards, the $w / f$ ratio was determined in order to reach an adoptedaverage spread of

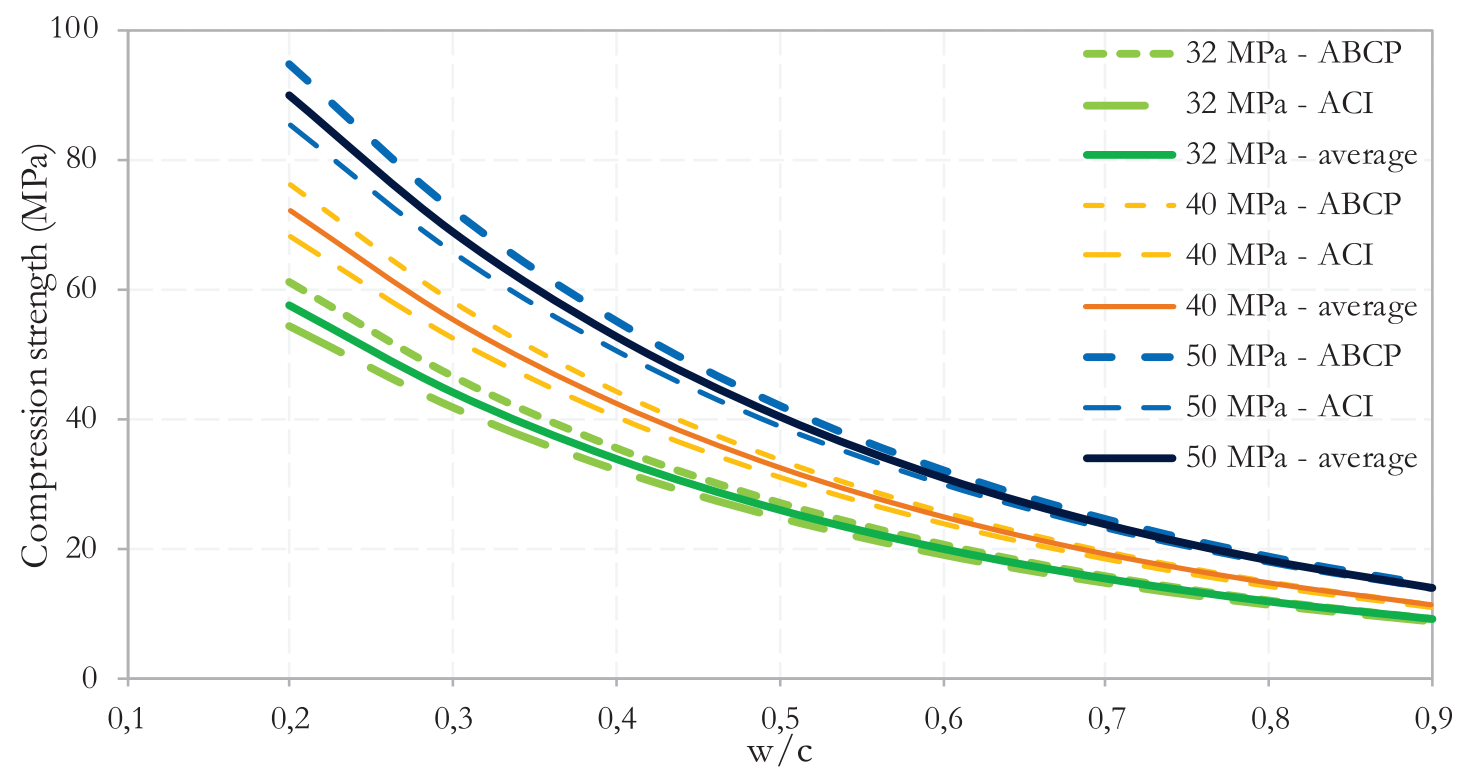

Figure 4

Models of Abrams curves obtained by the ABCP and ACl method and the average curve for each cement class 
$(265 \pm 10) \mathrm{mm}$. For all compositions, profiles with three or more points were obtained, except for the CPIII samples, with and without admixture, CP IV (II) without admixture and CPII-F with admixture, which reached the desired spread diameter in the first attempt.

The water reduction was defined as a relation of the $w / f$ ratio of mortars with the same spreading, without and with admixture, according to equation (1).

Water reduction $=1-\left(\frac{\left(\frac{w}{f}\right)_{\text {with admix. }}}{\left(\frac{w}{f}\right)_{\text {without admix. }}}\right)$

Where $(w / f)_{1}$ represents the water/fines ratio, per mass, of the composition and the index $i$ indicates whether the composition has superplasticizer admixture or not.

\subsubsection{Cement reduction, binder efficiency, $\mathrm{CO}_{2}$ emission}

Simplified indices were used to evaluate the performance of cements: (i) reduction of cement consumption in concrete; (ii) binder intensity $(B I)$, which relates the total amount of binders in the concrete divided by their compressive strength, according to equation (2); and (iii) carbon intensity $(\mathrm{Cl})$, indicating the environmental impact by the relation between $\mathrm{CO}_{2}$ mass emitted per the compres- sive strength of concrete, according to equation (3) [5].

$B I=\frac{C_{c}}{f_{c}}$

$C I=\frac{E_{c o 2}}{f_{c}}$

Where: $C_{c}$ is the cement consumption for a cubic meter of concrete, in $\mathrm{Kg} \cdot \mathrm{m}^{-3} ; f_{c}$ is the compressive strength of the concrete, in $\mathrm{MPa}$; and $\mathrm{E}_{\mathrm{CO} 2}$ is the total $\mathrm{CO}_{2}$ emissions generated by the production and transport of the materials, in $\mathrm{Kg}^{-3}{ }^{-3}$.

For all of these analyzes, correlations were inferred about theoretical concretes composed of the same mortars of the study of consistency and estimated compressive strength of $30 \mathrm{MPa}$, presenting slump between 75 and $100 \mathrm{~mm}$ and maximum aggregate diameter equal to $20 \mathrm{~mm}$ [27], based on studies of the Brazilian Portland Cement Association (ABCP) [28] and American Concrete Institute $(\mathrm{ACl})$ [27]. To simplify the analysis, the correction of mortar admixture content for concrete was not considered.

The water/cement ratio $(\mathrm{w} / \mathrm{c})$ determination, corresponding in this case to the $w / f$ ratio, occurred by correlation of the theoretical Abrams curve, obtained by the ABCP Abrams curves [28] and adjustments of the ACl Abrams curve [27], considering the class of each cement, according to the model presented in Figure 4.
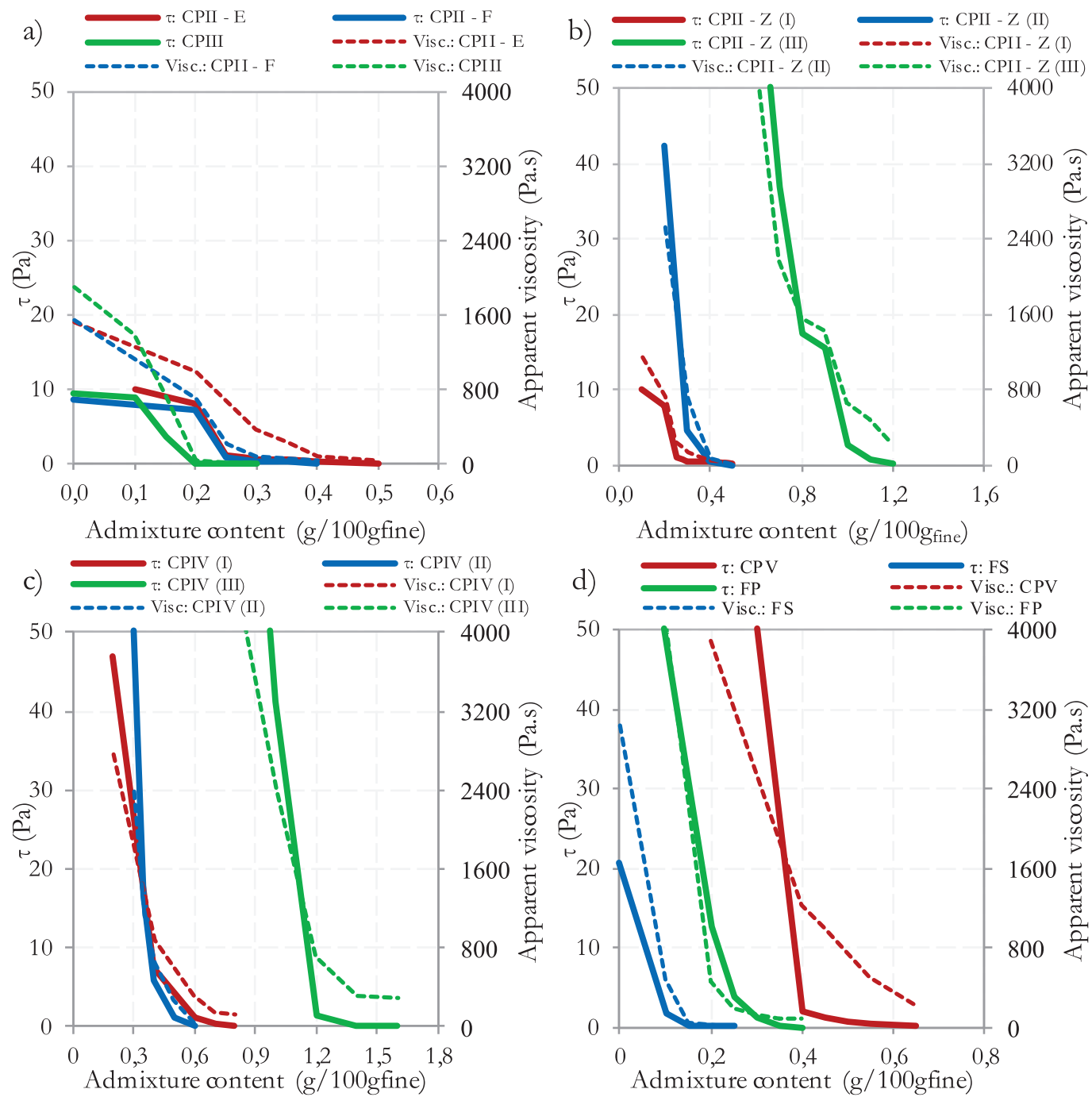

Admixture content $\left(\mathrm{g} / 100 \mathrm{~g}_{\text {fine }}\right)$
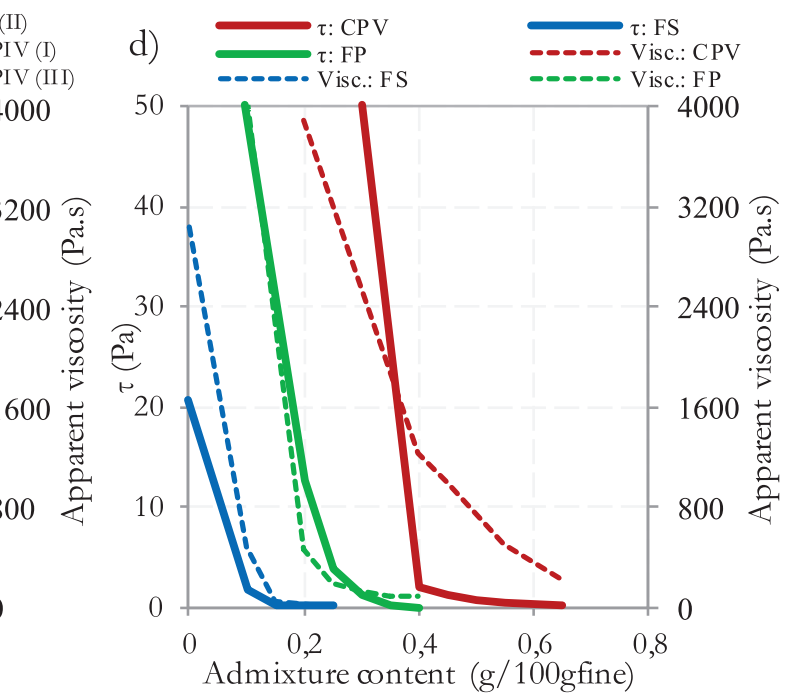

\section{Figure 5}

Deflocculation curves, analyzed by shear stress and apparent viscosity, for: (a) cements with slag and CPII-F; (b) CPII-Z; (c) CPIV; and (d) CPV, FS and FP 
Consumption of superplasticizer admixture for different cements and their binder efficiency

Table 4

Optimum content and specific consumption of superplasticizer by type of material

\begin{tabular}{|c|c|c|c|c|}
\hline Addition type & Material & $\begin{array}{l}\text { Optimum content } \\
\left(g_{\text {admix. }} / 100 g_{\text {fine }}\right)\end{array}$ & $\begin{array}{c}\text { Specific volumetric } \\
\text { consumption } \\
\left(g_{\text {admix. }} / \mathrm{cm}^{3} \text { fine }\right)\end{array}$ & $\begin{array}{c}\text { Specific superficial } \\
\text { consumption } \\
\left(m_{\text {gadmix }} / \mathrm{m}^{2} \text { fine }\right)\end{array}$ \\
\hline \multirow{2}{*}{ Slag } & CPII-E & 0.45 & 0.014 & 4.0 \\
\hline & CPIII & 0.25 & 0.007 & 2.5 \\
\hline \multirow{6}{*}{ Pozzolan } & CPII-Z (I) & 0.30 & 0.009 & 2.3 \\
\hline & CPII-Z (II) & 0.40 & 0.012 & 3.4 \\
\hline & CPII-Z (III) & 1.10 & 0.033 & 4.6 \\
\hline & CPIV (I) & 0.70 & 0.021 & 5.6 \\
\hline & CPIV (II) & 0.50 & 0.016 & 3.4 \\
\hline & CPIV (III) & 1.40 & 0.044 & 3.3 \\
\hline Filler & CPII-F & 0.35 & 0.011 & 3.0 \\
\hline \multirow{3}{*}{-} & CPV & 0.55 & 0.017 & 3.4 \\
\hline & FP & 0.35 & 0.010 & 0.9 \\
\hline & FS & 0.20 & 0.006 & 1.7 \\
\hline
\end{tabular}

The cement consumption of the composite without admixture was determined by fixing the water consumption at $200 \mathrm{~kg} \cdot \mathrm{m}^{-3}$ [27]. As shown in the study of Assaad [29], it was considered that there is a correlation between the spreading of mortars in a flow-table and the slump of concrete produced with the same mortar, allowing the readjustment of cement and water by the spreading in flow-table. In concrete optimized with admixtures, it was used the same ratio $w / f$ from the dosage of the concretes without admixture. The volume of water was readjusted by the water reduction capacity obtained in the consistency study and, thus, the consumption of cement was corrected. It was considered that even with the reduction of the paste volume, there was still enough paste to fill all the voids between the grains and this reduction was compensated by the addition of the same volume in sand, maintaining the mortar content. The influences caused by the reduction of paste content were disregarded for simplification of analyzes.

To calculate the $\mathrm{CO}_{2}$ emission factors, simplifications were made. From 88.6 to $92.2 \%$ of the environmental impacts related to concrete production refer to cement production [30]. $\mathrm{CO}_{2}$ emission factors for cement were obtained by the study of Oliver [31], where the impacts of milling, transport and drying of the additions were neglected. It was also adopted that the impacts related to supplementary cementitious materials (SCM) are allocated to their generators. From this scenario, the national average emission data [32] and the normalized clinker contents [31], the emission for different cements was estimated by the emission factor of $821 \mathrm{~kg}_{\mathrm{CO}_{2}}$. ton-1 clinker. For the environmental impacts caused by the admixture production process, it was considered the maximum emission factor obtained by the technical datasheets of the quoted admixtures, equivalent to $1.86 \mathrm{Kg}_{\mathrm{CO}_{2}} \cdot \mathrm{Kg}^{-1}$ admix . Therefore, $\mathrm{E}_{\mathrm{CO}_{2}}$ adopted is the sum of the products of consumption and emission factor of the cement and admixture contained in the concretes.

\section{Results and discussions}

\subsection{Admixture consumption}

The deflocculation curves used to determine the saturation point of the superplasticizer admixture are shown in Figure 5. A Figure 5-a shows the deflocculation curves of the CPII-E, CPII-F and CPIII cements. It was observed that CPIII presents the lowest admixture consumption among the three, with an optimum admixture

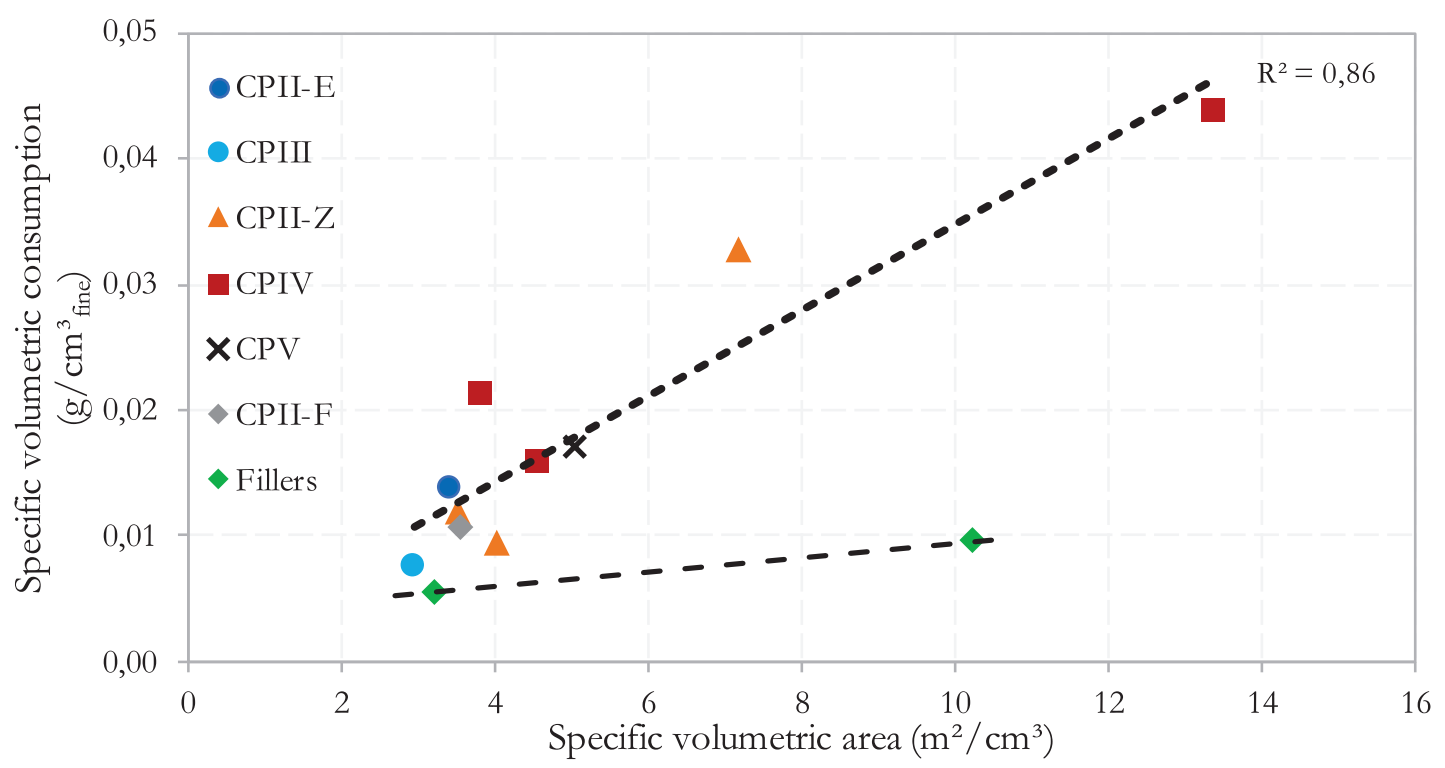

Figure 6

Optimum admixture content of the materials according to their specific surface areas 
content of $0.25 \mathrm{~g} .100 \mathrm{~g}^{-1}$ fine, followed by CPII-F, with $0.35 \mathrm{~g} .100 \mathrm{~g}^{-1}{ }_{\text {fine }}$, and CPII- E, with $0.45 \mathrm{~g} .100 \mathrm{~g}^{-1}{ }_{\text {fine }}$.

The curves of CPII-Z cements are shown in Figure 5-b. It is noticed that there is greater variation of the admixture consumption among them, being CPII-Z (III) the greater one, followed by CPII-Z (II) and CPII-Z (I), consuming $0.3,0.4$ and $1.1{\mathrm{~g} .100 \mathrm{~g}^{-1}}_{\text {fine }}$, respectively. For CPIV cements, the results are shown in Figure 5-c. The CPIV (I) consumed more superplasticizer, while the CPIV (II) and the CPIV
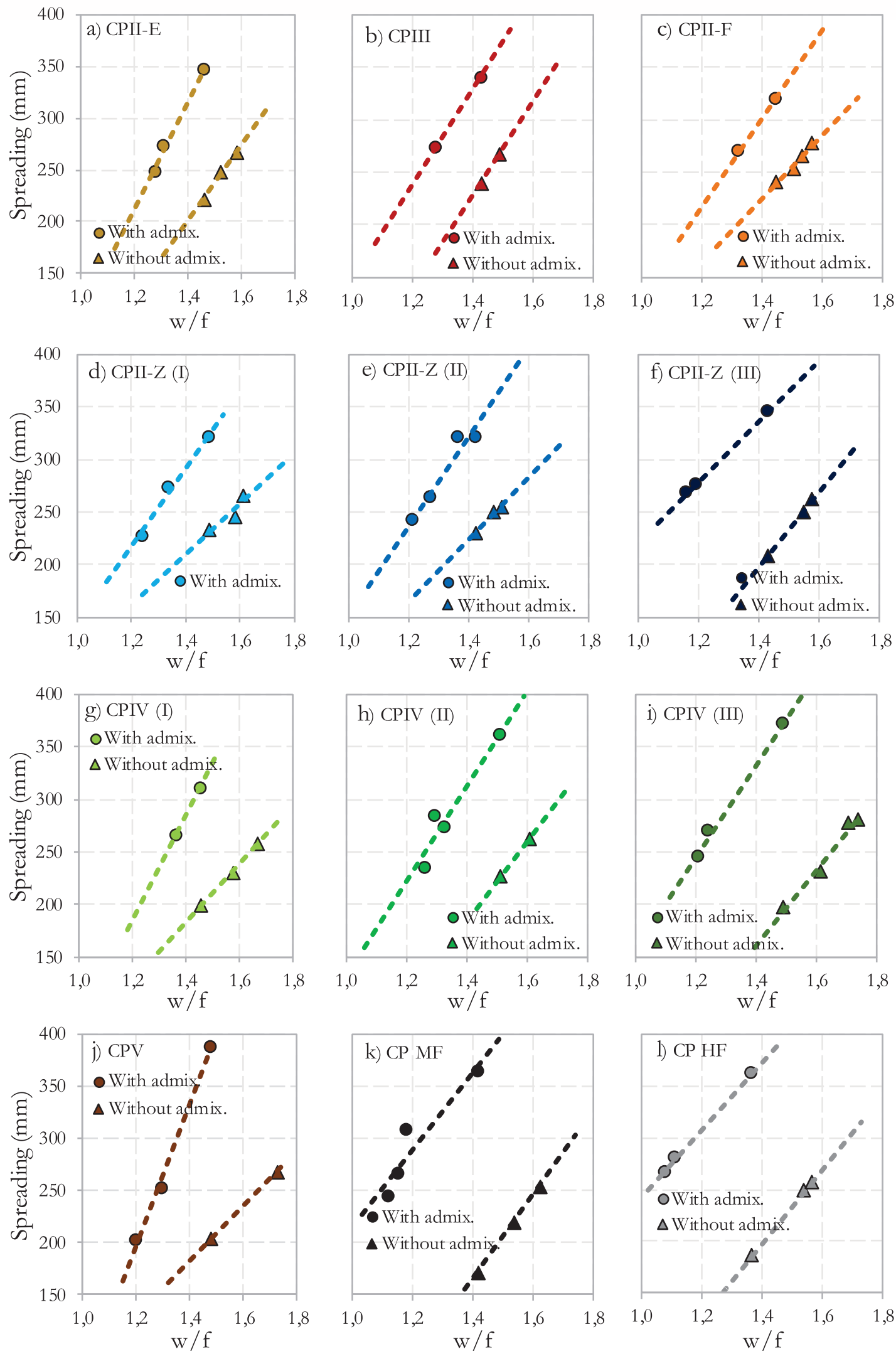

Figure 7

Correlation between spreading of the mortars with and without admixture and the relation $\mathrm{w} / \mathrm{f}$ (in volume), where they correspond to: (a) and (b) cements with slag; (c) CPII-F; (d), (e), (f), (g), (h) and (i) pozzolanic cements; (j) CPV; and (k) and (I) fillers 
(III) presented significantly lower intakes. The obtained optimum contents correspond to $1.4,0.7$ and $0.5{\mathrm{~g} .100 \mathrm{~g}^{-1}}_{\text {fine }}$, respectively. The optimum admixture contents for CPV, FS and FP correspond, respectively, to $0.55,0.2$ and $0.35 \mathrm{~g} .100 \mathrm{~g}^{-1}$ fine and are indicated in Figure 5-d. All data were compiled and added to the admixture-specific consumption results in Table 4. It can be observed that CPIV (III) was the material with the highest consumption of admixture, but with a similar specific consumption as the majority. Thus, consumption was influenced by high specific area and high form factor. The CPIV (I), although consuming half of the admixture in relation to the CPIV (III), presents the highest specific consumption among the materials, showing that the material of this cement demands more admixture. The variety of pozzolan types, due to their geographic distribution [33], is one of the factors that can strongly influence this result, along with clinker substitution content and material production variations.
Similar phenomena can be observed in CPII-Z cements, which have a $100 \%$ variation between CPII-Z (III) and CPII-Z (I).

Comparing all cements, there is a very open range of consumption, between 7 and $44 \mathrm{mg} \mathrm{cm}^{-3}$ fine, a variation of up to 6.3 times. The use of excess dispersant admixtures may negatively alter the rheological behavior of the composition, affecting the thixotropy and the viscosity of the mixture [15], indicating the need to control its use. The fillers presented the lowest specific admixture consumption among all materials studied due to the difference in surface charges $[12,15]$. However, for FP, due to its high specific area, the admixture consumption was similar to the other materials studied, while the FS, that presents smaller specific superficial area, presented lower consumption among all materials. Figure 6 shows a correlation between the specific area (BET) of the materials and the consumption of admixture, where it is possible to obtain a
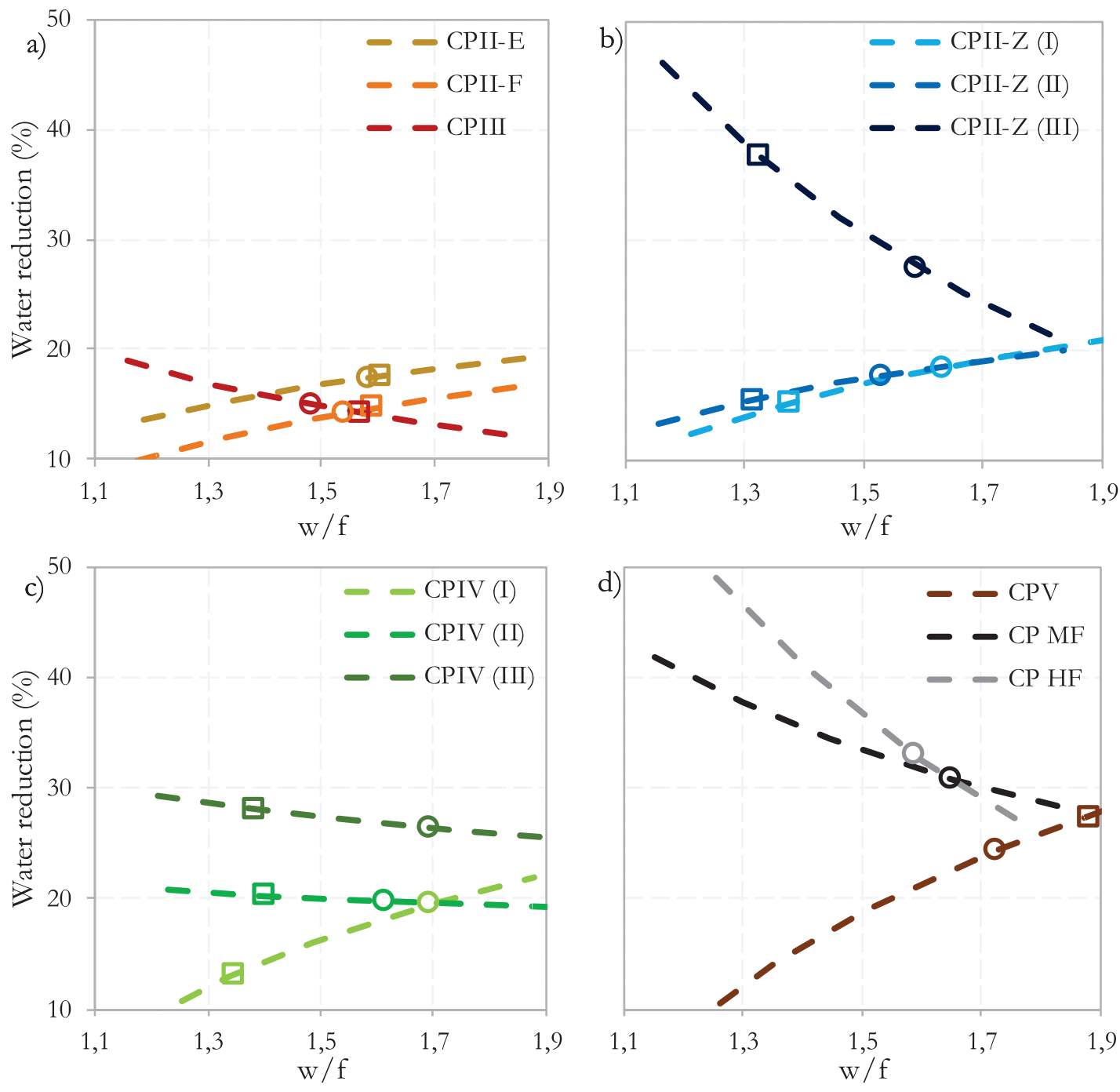

\section{Figure 8}

Water reduction in each composition with optimum superplasticizer content as a function of the $\mathrm{w} / \mathrm{f}$ ratio (in volume) of the mortar without admixture for the same spreading. Circles represent the reduction for mortars that presents spread of $265 \mathrm{~mm}$ and squares represent reduction to concretes with $30 \mathrm{MPa}$, using an average curve of Abrams 
correspondence with $\mathrm{R}^{2}$ above 0.85 for the cements. In the analysis considering the fillers, this index decreases to less than 0.60 due to differences in surface nature between materials $[12,15]$.

\subsection{Mortar consistency and water reduction}

The mortars with cement composed with FS had the optimum

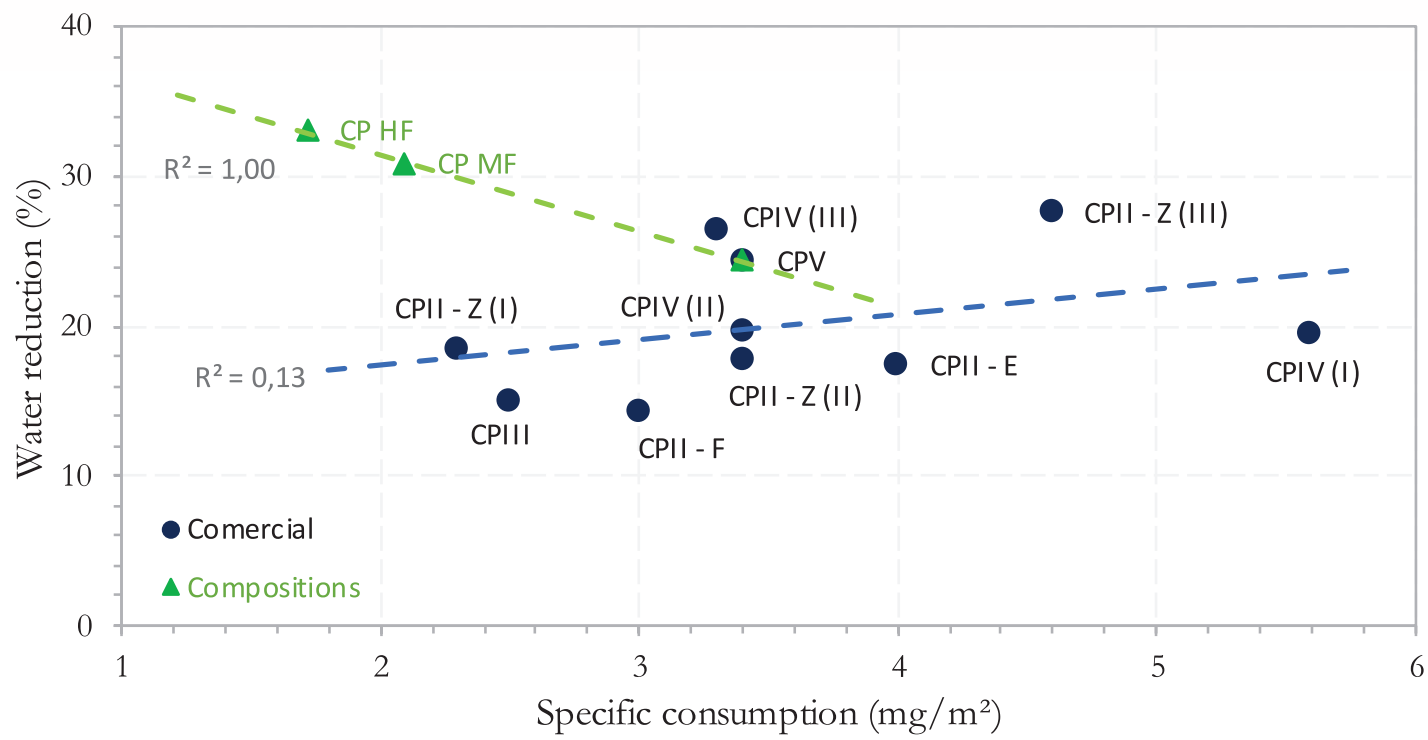

\section{Figure 9}

Water reduction in mortars with spreading, in flow-table, of $265 \mathrm{~mm}$ in function of the specific consumption of admixture superplasticizer

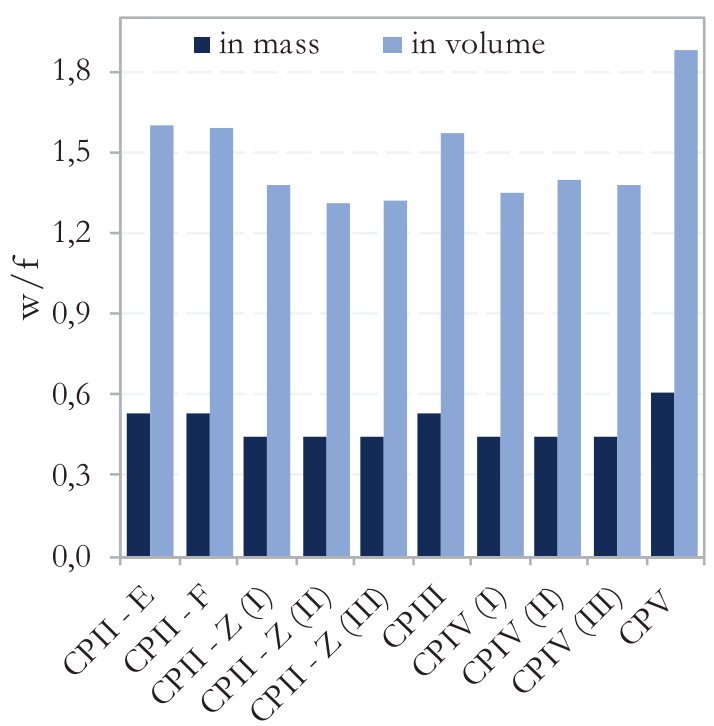

a

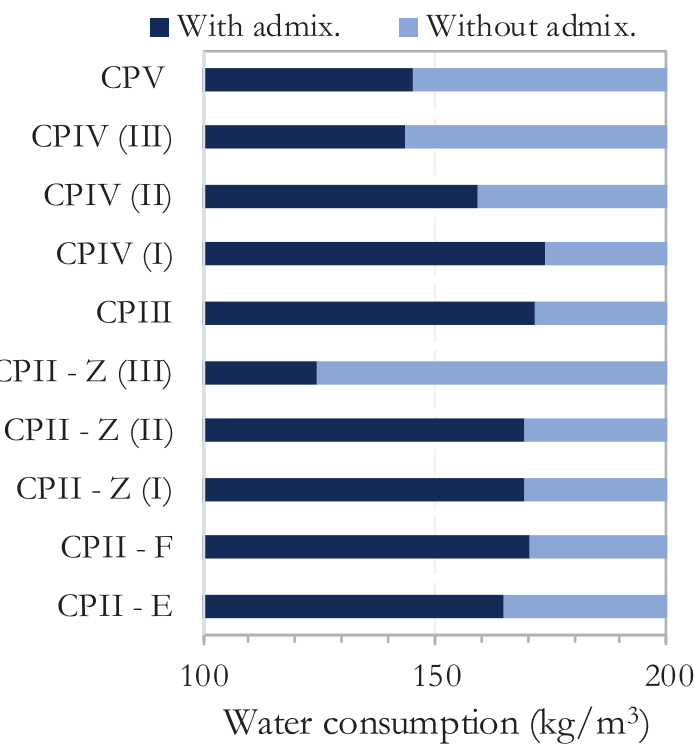

(b)

\section{Figure 10}

a) water/fine ratio, in mass and volume, of each theoretical concrete, without admixture, for estimated compressive strength of $30 \mathrm{MPa}$; and (b) water consumption for the concrete of $30 \mathrm{MPa}$ without admixture, $200 \mathrm{~kg} \cdot \mathrm{m}^{-3}$, and with admixture

\section{Table 5}

Superplasticizer admixture consumption for compositions of fines with limestone filler, obtained by weighting proportionally the raw materials

\begin{tabular}{|c|c|c|c|}
\hline Fine compositions & $\begin{array}{c}\text { Admixture optimum content } \\
\left(\mathrm{g}_{\text {admix }} / 100 \mathrm{~g}_{\text {fine }}\right)\end{array}$ & $\begin{array}{c}\text { Specific volumetric } \\
\text { consumption } \\
\left(g_{\text {admix. }} / \mathrm{cm}^{3}{ }_{\text {fine }}\right)\end{array}$ & $\begin{array}{c}\text { Specific superficial } \\
\text { consumption } \\
\left(\mathrm{m}_{\text {gadmix. }} / \mathrm{m}^{2}{ }_{\text {fine }}\right)\end{array}$ \\
\hline CP MF & 0.455 & 0.013 & 2.09 \\
\hline $\mathrm{CPHF}$ & 0.354 & 0.010 & 1.72 \\
\hline
\end{tabular}


admixture content adjusted proportionally to the content of each raw material and according to the superplasticizer admixture consumption study. For CP MF and CP HF mortars, superplasticizer dosages of 0.46 and $0.35 \mathrm{~g} 100 \mathrm{~g}^{-1}$ fine were used, respectively, according to. For the other mortars, the admixture contents determined in the study of the consumption of superplasticizer were used.

The comparison between the spreading profiles of the mortars without and with admixture is shown in Figure 7 . It is noted that most of the compositions did not show a parallelism to the profiles, indicating that the water reduction capacity varies according to the water content.

The water reduction capacity in each composition, maintaining the spreading corresponding to the respective mortar without admixture, is presented in Figure 8. CPIV (II) and CPIV (III) cements, shown in Figure 8-c, did not vary much as a function of the w/f ratio of the mortars, whereas, for the others, the cements varied significantly. The compositions CPII-Z (III), CP MF and CP HF, although with greater variations, presented the greatest water reductions. When fixing the mortars to $265 \mathrm{~mm}$ of spread diameter (rheological condition determined as a limit for significant effects of visually perceptible segregation), it was possible to verify if there is a relation between the specific consumption of superplasticizer admixture and the respective capacity to reduce water in mortars. As indicated in Figure 9, it was possible to observe that the increase of limestone filler content in the compositions increases the capacity to reduce water (since well dispersed by the admixture), while the admixture consumption also decreases due to the dilution of clinker by the filler and consequent reduction of the surface charges of the particles in the suspension. However, there is no clear correlation between these parameters for commercial cements, possibly due to differences in the nature of the materials. Analyzing the specific volumetric consumption, it is possible to observe that the use of limestone filler as a substitute for cement allowed to reduce the consumption of admixture per volume of fines used, indicating a possible reduction of costs for these types of composition.

\subsection{Reduction of cement consumption in concrete and environmental impact indexes}

The $\mathrm{w} / \mathrm{f}$ ratio corresponding to $30 \mathrm{MPa}$ was determined by the average Abrams curve. The amount of initial water, equivalent to $200 \mathrm{~kg} \cdot \mathrm{m}^{-3}$, was reduced using the correlations of the water reduction study, indicated in the markers of Figure 8. Thus, the water consumption for the theoretical concretes was estimated, according to Figure 10, ranging from 124.5 to $173.7 \mathrm{~kg} . \mathrm{m}^{-3}$.

From the new water consumption, the cement consumption could be readjusted, as shown in Figure 11, considering the minimum volume of paste to fill the intergranular voids. The application of the superplasticizer in the mixture was able to provide the reduction of cement consumption between 13.1 and $37.7 \%$. of the analyzed theoretical concretes without application of the admixture, the lowest cement consumption corresponds to $327 \mathrm{~kg} \cdot \mathrm{m}^{-3}$, while with its use it was possible to predict formulations with $240 \mathrm{~kg}_{\text {cement }} \cdot \mathrm{m}^{-3}$ using CPV. It should be noted that CPII-Z (III) that, with superplasticizer use, presents lower cement consumption at $30 \mathrm{MPa}$ than class 40MPa cements.

Figure 12 shows the results of the $\mathrm{BI}$ calculations for the theoretical concretes with different cements. The use in optimum content of superplasticizer admixture provided reduction of this index, indicating increase of the binder efficiency. When it was not used, $\mathrm{BI}$ varied between 12.6 and $15 \mathrm{~kg} \cdot \mathrm{m}^{-3} \mathrm{MPa}^{-1}$, while with the use of the admixture the index varied between 9.2 and $13 \mathrm{~kg} \cdot \mathrm{m}^{-3} \mathrm{MPa}^{-1}$, limits corresponding to CPII-Z (III) and CPIV (I), respectively. These values are commonly found in the literature [5]. The percentage reduction is equivalent to the reduction in cement consumption. The impact of the use of the superplasticizer was also positive

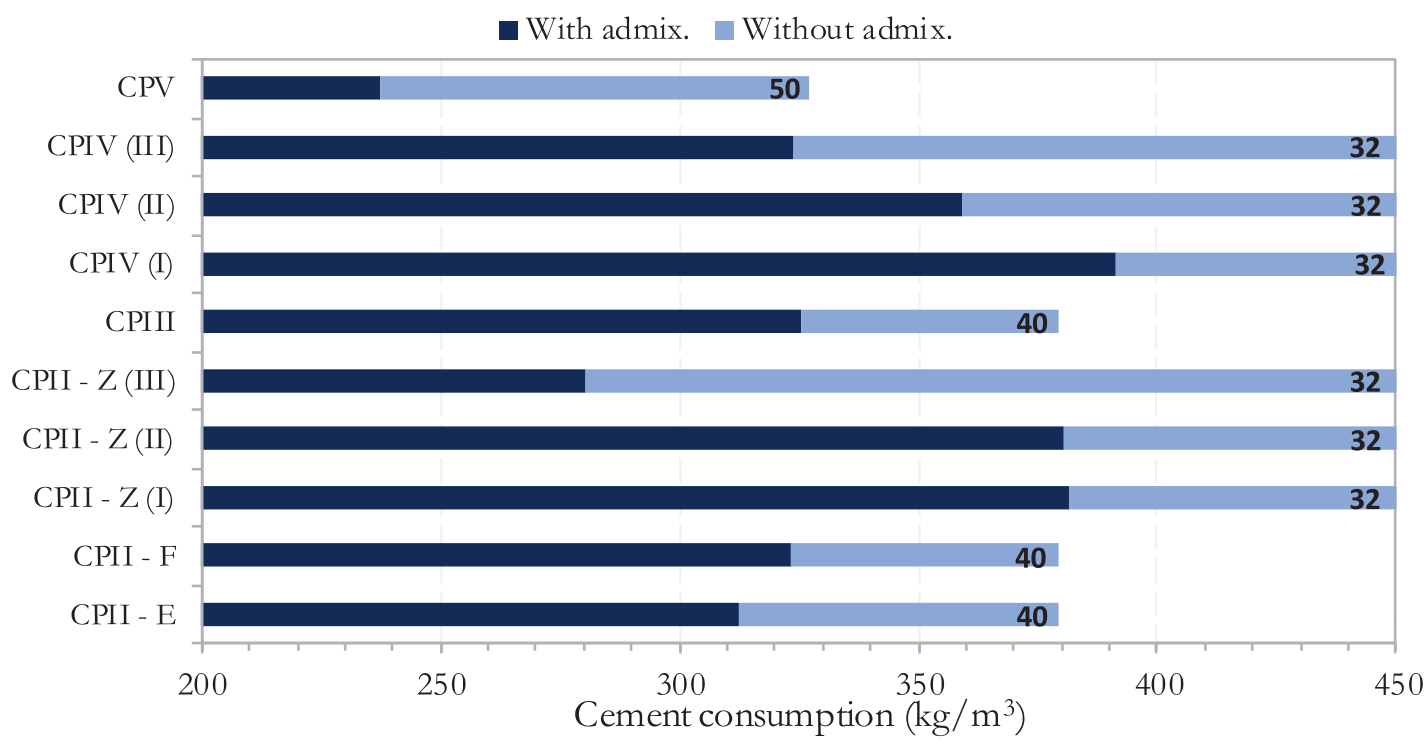

Figure 11

Cement consumption for concretes of the same strength and corresponding reduction for each cement type. The numbers on each bar indicate the strength class of the cements, in MPa 


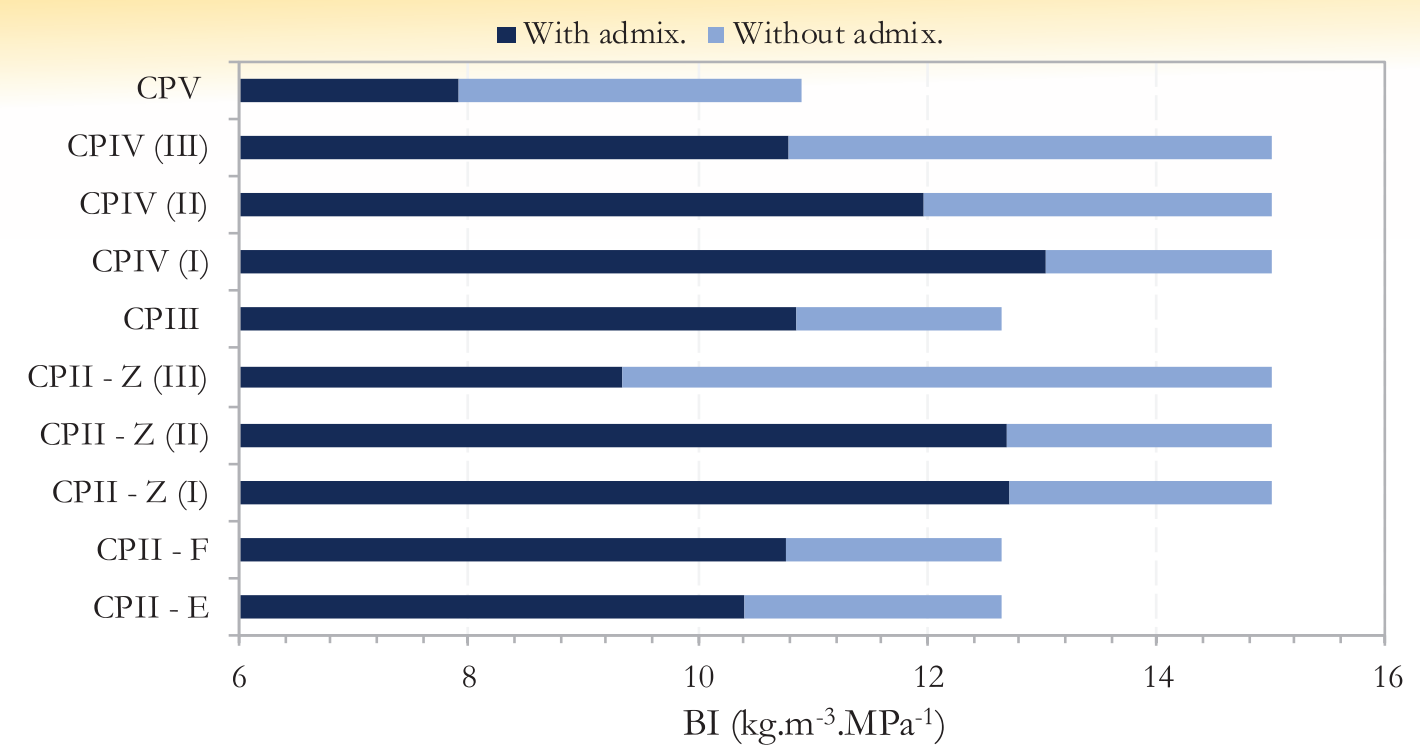

\section{Figure 12}

Binder intensity and their reduction with the use of superplasticizer for theoretical concretes with different types of cement and theoretical compressive strength of $30 \mathrm{MPa}$

when the carbon intensity was analyzed, which was reduced for all concretes studied, as indicated in Figure 13. For concretes without admixture, $\mathrm{Cl}$ varied between 2.6 and $11.6 \mathrm{~kg}_{\mathrm{CO}_{2}} \cdot \mathrm{m}^{-3}$ When the admixture was used, the $\mathrm{Cl}$ ranged from 2.3 to $10 \mathrm{~kg}_{\mathrm{CO}_{2}} \cdot \mathrm{m}^{-3} \cdot \mathrm{MPa}^{-1}$, values commonly found in the literature [5], and provided a reduction between 10.1 and $36.1 \%$. Although the greatest reduction occurred for the CPII-Z (III) composition, due to its higher reduction of cement, the lower values are associated to CPIII, since it presents a high percentage of additional cementitious material in its composition.

\section{Conclusions}

By means of the study to determine the optimum superplasticizer content, a polycarboxylate ether base admixture, it was possible to observe significant variation in its consumption by the cements, reaching values between 7 and $44 \mathrm{mg}_{\mathrm{cm}}{ }^{-3}$ fine, while the specific consumption varied from 2.3 to $5.6 \mathrm{mg} \cdot \mathrm{m}^{-2}$. Thus, this kind of study regarding superplasticizer admixture demand for different cements allows for the reduction of costs in concrete production. The fillers were, among all the analyzed materials, the ones that presented lower specific consumption, indicating that they were supplementary materials with potential to reduce the admixture consumption. By the consistency (flow-table) study, it was observed that the water reduction capacity in mortars with optimum superplasticizer content varies with the $w / f$ ratio used. CPV and CPII-Z (III) cements and the compositions with filler in the mortars presented a greater potential of water reduction. Also, the increase of the filler content in the compositions with CPV presented capacity to reduce the admixture consumption due to the dilution of cement concentration and the superficial charges associated with the binder.

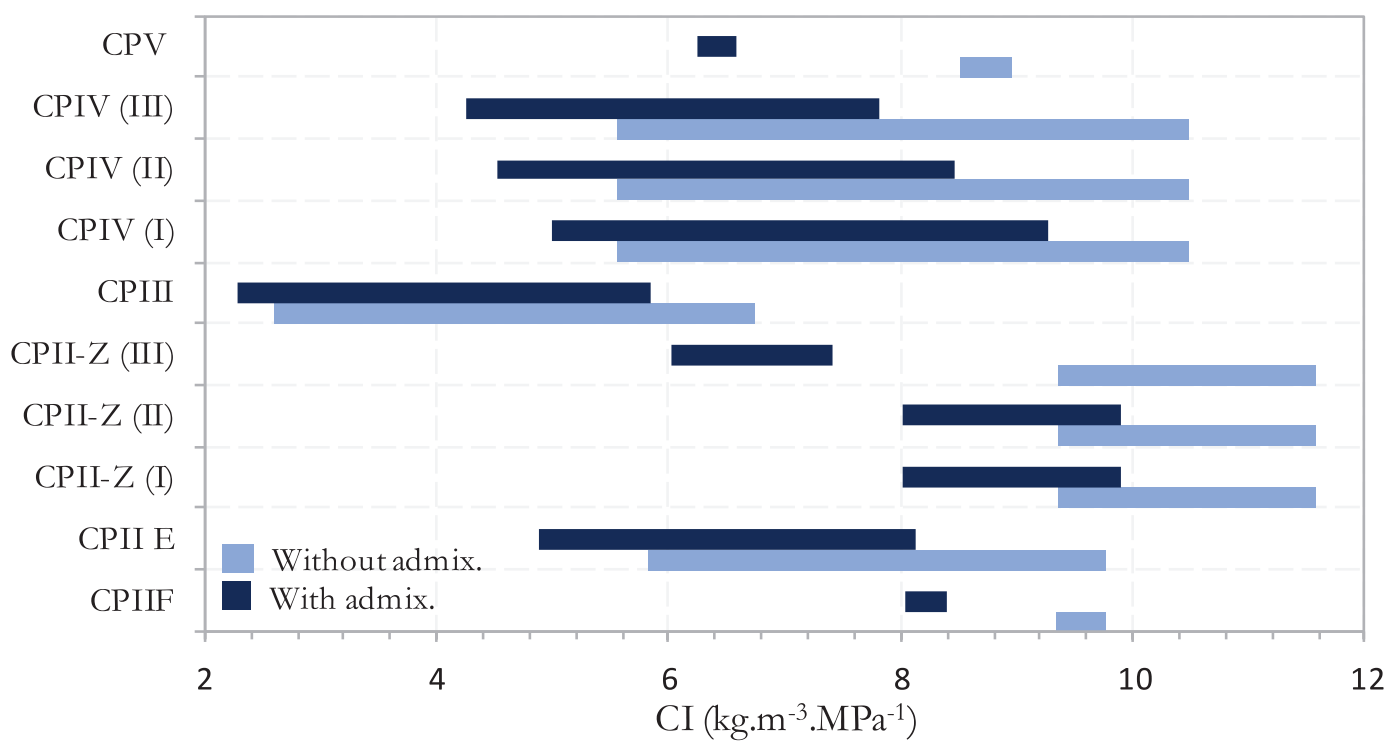

\section{Figure 13}

Carbon intensity for theoretical concretes, with estimated compressive strength of $30 \mathrm{MPa}$, depending on the type of cement 
By inference, it was possible to estimate the potential reduction of cement consumption by up to $37.7 \%$ in concrete, varying with the reduction of water. With the use of CPV (high clinker), it is possible to produce concretes, with estimated compressive strength of $30 \mathrm{MPa}$ and with $240 \mathrm{~kg}_{\text {cement }} \mathrm{m}^{-3}$, provided that the volume of paste is enough to occupy the voids between the aggregates. CPII-Z (III), class $32 \mathrm{MPa}$, presented greater capacity of reduction of cement. These reductions allowed to minimize binder and carbon intensity by up to 37.7 and $36.1 \%$, respectively, demonstrating that the use of optimized superplasticizer content has the potential to improve cement efficiency and reduce environmental impacts.

\section{Acknowledgments}

The authors would like to thank the Coordination for the Improvement of Higher Education Personnel (CAPES) for the master's scholarships financed, to the microstructure laboratory (LME / PCC) of the Polytechnic School of the University of São Paulo for the availability of laboratories and equipment, to the National Council for Scientific and Technological Development (CNPq) Brazil (Case 485340 / 2013-5) and to the doctors Roberto C. O. Romano and Rafael G. Pileggi for the assistance and discussions during the production of this work.

\section{Bibliography}

[1] J.F. Kasting, D. Catling, Evolution of a Habitable Planet, Annu. Rev. Astron. Astrophys. 41 (2003) 429-463. doi:10.1146/annurev.astro.41.071601.170049.

[2] T.F. Stocker, D. Qin, G.-K. Plattner, M. Tignor, S.K. Allen, J. Boschung, A. Nauels, Y. Xia, V. Bex, P.M. Midgley, Climate change 2013: The physical Science Basis. Contribution of Working Group I to the Fifth Assessment Report of the Intergovernamental Panel on Climate Change, Cambridge University Press, Cambridge, United Kingdom, and New York, NY, USA, 2014.

[3] UNITED NATIONS ENVIRONMENT PROGRAMME (UNEP), Sustainable building and construction: facts and figures, Ind. Environ. Sustain. Build. Constr. 26 (2003).

[4] E. Benhelal, G. Zahedi, E. Shamsaei, A. Bahadori, Global strategies and potentials to curb $\mathrm{CO} 2$ emissions in cement industry, J. Clean. Prod. 51 (2013) 142-161. doi:10.1016/j. jclepro.2012.10.049.

[5] B.L. Damineli, Conceitos para formulação de concretos com baixo consumo de ligantes: controle reológico, empacotamento e dispersão de partículas., text, Universidade de São Paulo, 2013. http://www.teses.usp.br/teses/disponiveis/3/3146/ tde-19092014-103459/ (accessed March 24, 2016).

[6] C.B.C. Corrêa, Estudo do desempenho dos aditivos plastificantes e polifuncionais em concretos de cimento portland tipo CPIII-40, Dissertação, Universidade Federal Fluminense, 2010.

[7] Associação Brasileira de Normas Técnicas (ABNT), NBR 11768: Aditivos químicos para concreto de cimento Portland, 2011.

[8] K.H. Khayat, Viscosity-enhancing admixtures for cementbased materials - An overview, Cem. Concr. Compos. 20 (1998) 171-188. doi:10.1016/S0958-9465(98)80006-1.
[9] A.M. Neville, Propriedades do Concreto, $5^{\text {a }}$ edição, Bookman Editora, 2015.

[10] V.C. Pandolfelli, I.R. Oliveira, A.R. Stuart, R.G. Pileggi, Dispersão e empacotamento de partículas: Princípios e aplicações em processamento cerâmico, Fazendo Arte Editorial, São Paulo, 2000.

[11] M.M. Alonso, M. Palacios, F. Puertas, Compatibility between polycarboxylate-based admixtures and blendedcement pastes, Cem. Concr. Compos. 35 (2013) 151-162. doi:10.1016/j.cemconcomp.2012.08.020.

[12] O. Burgos-Montes, M. Palacios, P. Rivilla, F. Puertas, Compatibility between superplasticizer admixtures and cements with mineral additions, Constr. Build. Mater. 31 (2012) 300309. doi:10.1016/j.conbuildmat.2011.12.092.

[13] E. Janowska-Renkas, The effect of superplasticizers' chemical structure on their efficiency in cement pastes, Constr. Build. Mater. 38 (2013) 1204-1210. doi:10.1016/j.conbuildmat.2012.09.032.

[14] S.K. Agarwal, I. Masood, S.K. Malhotra, Compatibility of superplasticizers with different cements, Constr. Build. Mater. 14 (2000) 253-259. doi:10.1016/S0950-0618(00)00025-8.

[15] R.C.O. Romano, M.S. Rebmann, H.M. Bernardo, J. Raucci, C. Massucato, R.J. Pileggi, Impact of particle packing on rheological properties of cementitious pastes dispersed with polycarboxylate, in: Annu. Trans. Nord. Rehology Soc., 2017: p. 8.

[16] Associação Brasileira de Normas Técnicas (ABNT), NBR 7214: Areia normal para ensaio de cimento - especificação, 2015.

[17] Grace Construction Products, Especificação de produto: ADVA CAST 527, (2016).

[18] M. Hunger, H.J.H. Brouwers, Flow analysis of water-powder mixtures: Application to specific surface area and shape factor, Cem. Concr. Compos. 31 (2009) 39-59. doi:10.1016/j. cemconcomp.2008.09.010.

[19] Associação Brasileira de Normas Técnicas (ABNT), NBR 7215: Cimento Portland - Determinação da resistência à compressão, 1996.

[20] F. de Larrard, T. Sedran, Optimization of ultra-high-performance concrete by the use of a packing model, Cem. Concr. Res. 24 (1994) 997-1009. doi:10.1016/00088846(94)90022-1.

[21] M.C. Limbachiya, T. Leelawat, R.K. Dhir, Use of recycled concrete aggregate in high-strength concrete, Mater. Struct. 33 (2000) 574. doi:10.1007/BF02480538.

[22] V. Bonavetti, H. Donza, G. Menéndez, O. Cabrera, E.F. Irassar, Limestone filler cement in low w/c concrete: A rational use of energy, Cem. Concr. Res. 33 (2003) 865-871. doi:10.1016/S0008-8846(02)01087-6.

[23] G. Rodríguez de Sensale, Strength development of concrete with rice-husk ash, Cem. Concr. Compos. 28 (2006) 158160. doi:10.1016/j.cemconcomp.2005.09.005.

[24] F.A. Cardoso, Método de formulação de argamassas de revestimento baseado em distribuição granulométrica e comportamento reológico., text, Universidade de São Paulo, 2009. doi:10.11606/T.3.2009.tde-21122009-125012.

[25] P.-C. Nkinamubanzi, P.-C. Aïtcin, Cement and Superplasticizer Combinations: Compatibility and Robustness, Cem. Concr. Aggreg. 26 (2004) 1-8. doi:10.1520/CCA12329. 
[26] Associação Brasileira de Normas Técnicas (ABNT), NBR 13276: Argamassa para assentamento e revestimento de paredes e tetos - Preparo da mistura e determinação do índice de consistência, 2005.

[27] M.L. Wilson, S.H. Kosmatka, Design and Control of Concrete Mixtures, 15 edition, Portland Cement Assn, Skokie, III, 2011.

[28] P.P.F. Rodrigues, Parâmetros de dosagem racional do concreto, Associação Brasileira de Cimento Portland (ABCP), 1983.

[29] J.J. Assaad, J. Harb, E. Chakar, Relationships Between Key ASTM Test Methods Determined on Concrete and ConcreteEquivalent-Mortar Mixtures, J. ASTM Int. 6 (2009) 1-13. doi:10.1520/JAI101735.

[30] J.A.R. de Lima, Avaliação das conseqüências da produção de concreto no Brasil para as mudanças climáticas., text, Universidade de São Paulo, 2010. doi:10.11606/T.3.2010. tde-23082010-105858.

[31] RELATÓRIO ANUAL 2013: Sindicato Nacional da Indústria do Cimento, (n.d.). http://www.snic.org.br/pdf/RelatorioAnual2013final.pdf (accessed June 4, 2017).

[32] V.C.H.C. Oliveira, B.L. Damineli, V. Agopyan, V.M. John, Strategies for the minimization of $\mathrm{CO} 2$ emissions from concrete, Ambiente Construído. 14 (2014) 167-181. doi:10.1590/S1678-86212014000400012.

[33] World Business Council for Sustainable Development (IEAWBCSD), Cement Technology Roadmap 2009, 2009. 